\title{
Micropropagation of Helianthemum lippii L.var sessifolium
}

\author{
Aya Mohui Aldeen Salih, Zainab Sabeeh Omran, Nabeel K. Al-Ani \\ College of Biotechnology Al-Nahrain University Iraq. Email: nkalani54@yahoo.com
}

Received: October 9, 2018 Accepted: December 10, 2018

doi:10.5296/jbls.v10i1.13754 URL: https://doi.org/10.5296/jbls.v10i1.13754

\begin{abstract}
The important of this plant coming from the symbiotic relation between this plant and truffles which is very important food. In an attempt to propagate this plant in vitro this research was conducted. The seeds were culture on MS basic medium, the seedling parts were isolated and cultured with MS medium supplemented with $0.5 \mathrm{mg} / \mathrm{l} \mathrm{NAA}$ and $2 \mathrm{mg} / \mathrm{l} \mathrm{BA}$. The shoots were rooted on basic medium and later the plantlets acclimatized on pots.
\end{abstract}

Keywords: micro-propagation, symbiotic relationship, Helianthemum lippii L.var sessifolium

\section{Introduction}

Helianthemum lippii L.var sessifolium (H. lippii) is a perpetual little brush, which found on sandy soils and sandy limestone gypsum low-lying in North African(Escudero, Martínez, De la Cruz, Otálora, \& Maestre, 2007; Gonçalves, Fernandes, Pérez-García, González-Benito, \& Romano, 2009; Raynaud, 1987). It is conveyed in the bioclimatic semi-dry (Belghith, 2003; Gonçalves et al., 2009) where it is appropriate to extreme climatic conditions in Southern Tunisia, this plant is also found in Iraqi desert where it is collected. It shows a critical biological, temperate and peaceful intrigue and assumes a significant part of a battle against desertification and the adjustment of powerless locales (Díez, Manjón, \& Martin, 2002). In addition, it has a restorative intrigue in light of the fact that the powder or the pack of the ethereal part is utilized to treat a coetaneous injury. This plant is known to be typically related to forsake truffles. H. lippii is the host plant for a few types of desert truffles, which have enthusiasm for sustenance, restorative and financial purposes, advancement of the provincial and neighbourhood populaces,(Mandeel \& Al-Laith, 2007; Plenchette \& Duponnois, 2005; SLAMA, FORTAS, NEFFATI, KHABAR, \& BOUDABOUS, 2006), and specifically Terfezia boudieri Chatin and Tirmania Nivea (Desf) (SLAMA et al., 2006). The nearness of H. lippii is in a persistent relapse. This plant is profoundly influenced by the adjustment in their floristic creation under the impact of overgrazing, arrive clearing and expanded peaceful 
care (Aïdoud, Le Floc'h, \& Le Houérou, 2006). H. lippii ends up jeopardized, the uncommon and endemic verdure of the western bowl of the Mediterranean Sea (Escudero et al., 2007). Every one of these qualities energizes us to attempt the in vitro engendering. In vitro culture is by all accounts an extremely intriguing contrasting option to safeguard $H$. lippii against the scourge of elimination under the impact of overgrazing, arrive clearing and expanded peaceful care... In this investigation, we endeavour to proliferate $H$. lippii by utilizing in vitro strategy.

\section{Materials and Methods}

Sterilization of Seeds: The seeds were collected from plants cultivated in a dessert of Iraq. The seeds were surface sterilized by $3 \%$ for 8 min commercial bleach solution, followed by rinsing in sterile distilled water three times for 5-10min until used.

Culture medium preparation

Murashige and Skoog medium(MS) was prepared according to the manufacturer company,(Murashige T, (1962)) all additives were added then the $\mathrm{pH}$ was adjusted by $0.1 \mathrm{~N}$ $\mathrm{NaOH}$ or $0.1 \mathrm{~N} \mathrm{HCl}$ to 5.8 then, sterilized by autoclaving $\left(121^{\circ} \mathrm{C}, 15\right.$ minutes). The prepared media distributed into sterile vials.

Seeds Culture: the sterile seeds were the culture on MS medium for about 15-20 days. The shoots, leaves, and roots were cut and used.

Shoot and root Culture: The shoots, leaves and roots isolated from seedlings were cultured on MS medium supplemented by $0.5 \mathrm{mg} / \mathrm{l} \mathrm{NAA}$ and $2 \mathrm{mg} / \mathrm{l} \mathrm{BAP}$

Callus culture: Same MS medium was used except the plant growth regulators were change as follow $2 \mathrm{mg} / \mathrm{l}$ for NAA and BAP

Rooting: All shoots between 1-3 cm long were transferred under a sterile condition to MS medium supplemented with different concentrations $1,2,3 \mathrm{mg} / \mathrm{l}$ of IBA.

Acclimatization

Plantlets with developed roots were transferred to plastic pots $(150 \mathrm{~g})$ containing a mixture of peat and perlite. Potted plantlets were placed in a growth chamber set at $80 \%$ relative humidity, $25 \pm 2{ }^{\circ} \mathrm{C}$, with a $16 \mathrm{~h}$ photoperiod, for two months, then transferred to a greenhouse under natural daylight conditions at $25^{\circ} \mathrm{C}$ temperature.(Amina \& Mohamed, 2014). These plantlets are growing well without any phenotypic aberrations.

\section{Results}

In the first experiment, $80 \%$ per cent of the seeds were germinated. This experiment indicates that the viability of the seeds was high. The stems, leaves, and roots were isolated and used in the second experiment.

In the second experiment, the parts mentioned above were cultured on MS medium supplemented with concentrations of $\operatorname{BAP}(0.5,1,1.5,2 \mathrm{mg} / \mathrm{l})$ as a cytokinin . It seems from figure 1 that callus induction in this plant needs higher concentrations of BAP while for 


\section{Macrothink

multiplication the shoots and leaves need no BAP. This result may explain that the segments which isolated may result incompatible with any information available for other plants (Thorpe et al., 2008). However, in kinetin (Another cytokinin ) with the same concentrations, the responses were vice versa. The higher concentrations have fewer responses in shoot length, leaves and even a callus. (Figure 2) (Thorpe et al., 2008).

In the third experiment the BAP plus NAA were added and Kin plus NAA. But there was no growth in all samples in culture. Apart from some growth in lower concentrations (figure 3). Nevertheless, the callus production was more in high concentrations (figure 4). (Thorpe et al., 2008).

All shoots "between" $1-3 \mathrm{~cm}$ were transferred to pots with soil, acclimatized and rooted by increasing the humidity of the pots by polyethene bags. After about 2-3 weeks the bags were removed and humidity decreased gradually. (Amina \& Mohamed, 2014).

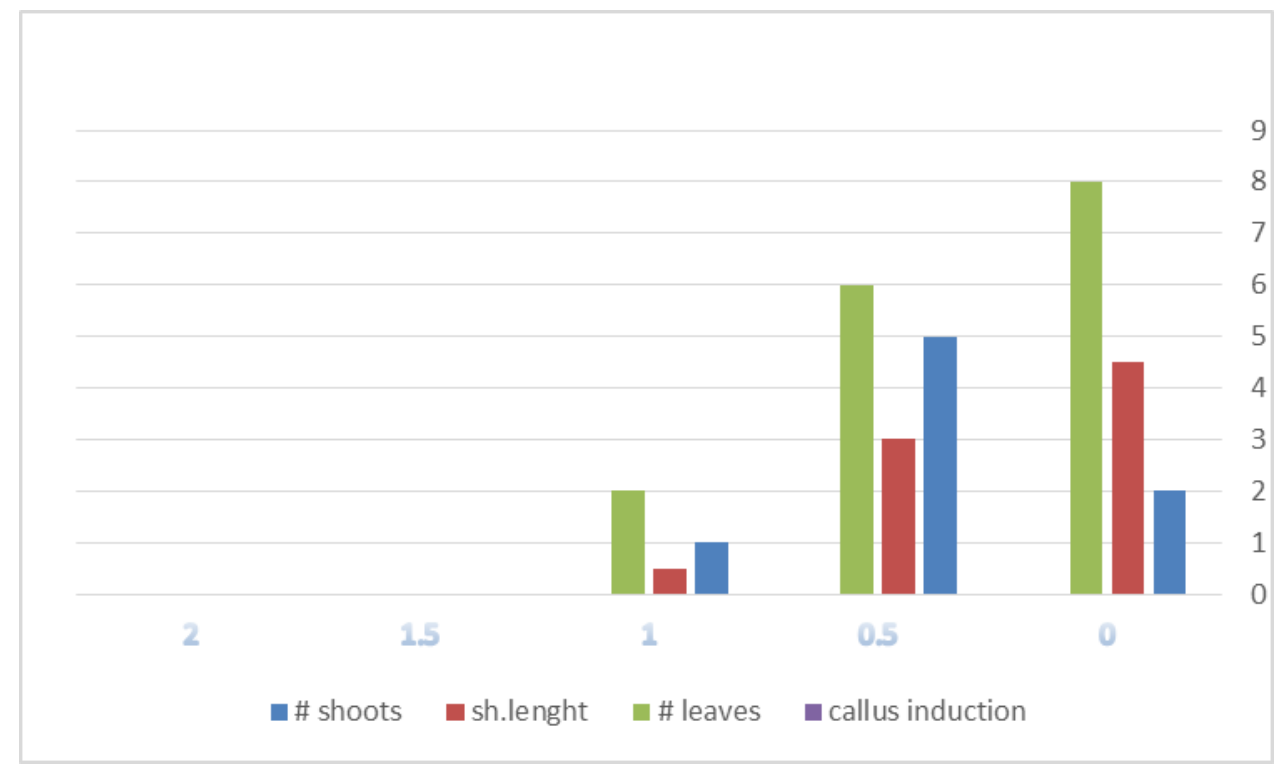

Figure 1. Shoot, leaves, and callus production on MS with different concentrations of BAP ( $\mathrm{x}$ axes) 


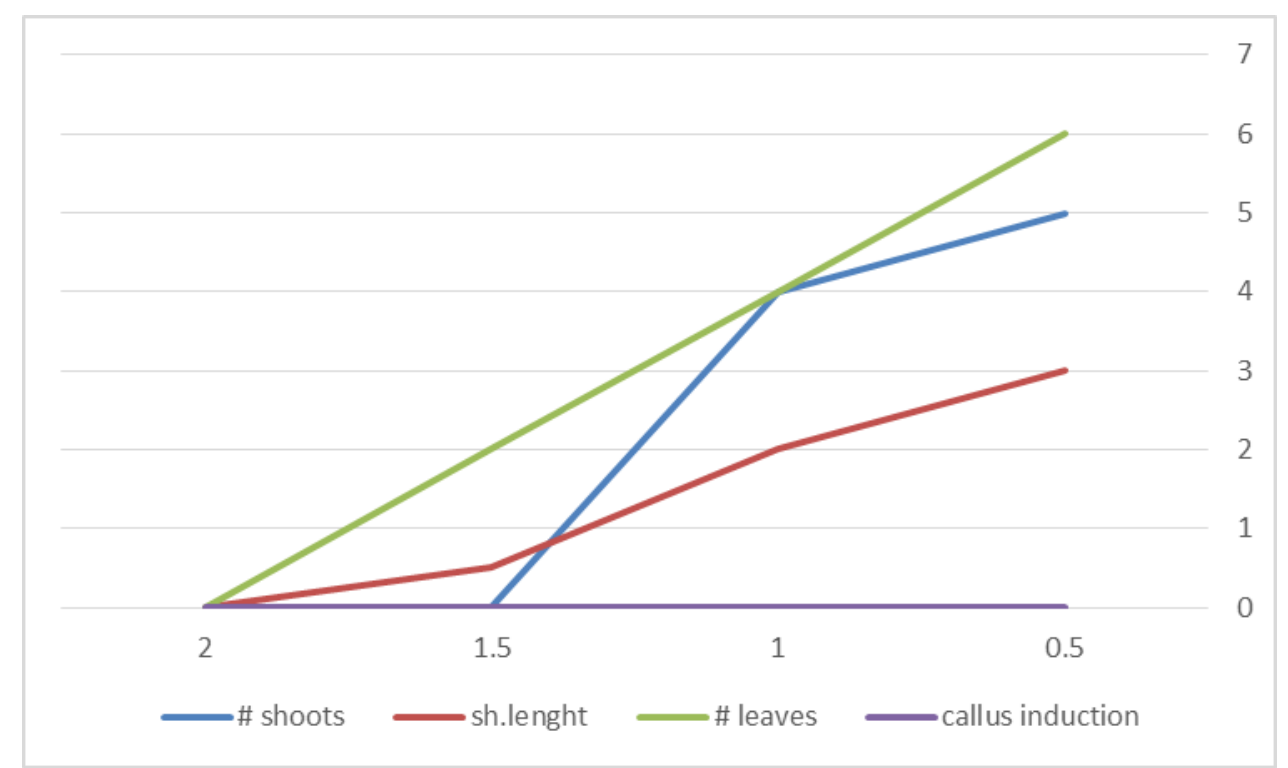

Figure 2. Shoot, leaves, and callus production on MS with different concentrations of Kinetin (x axes)

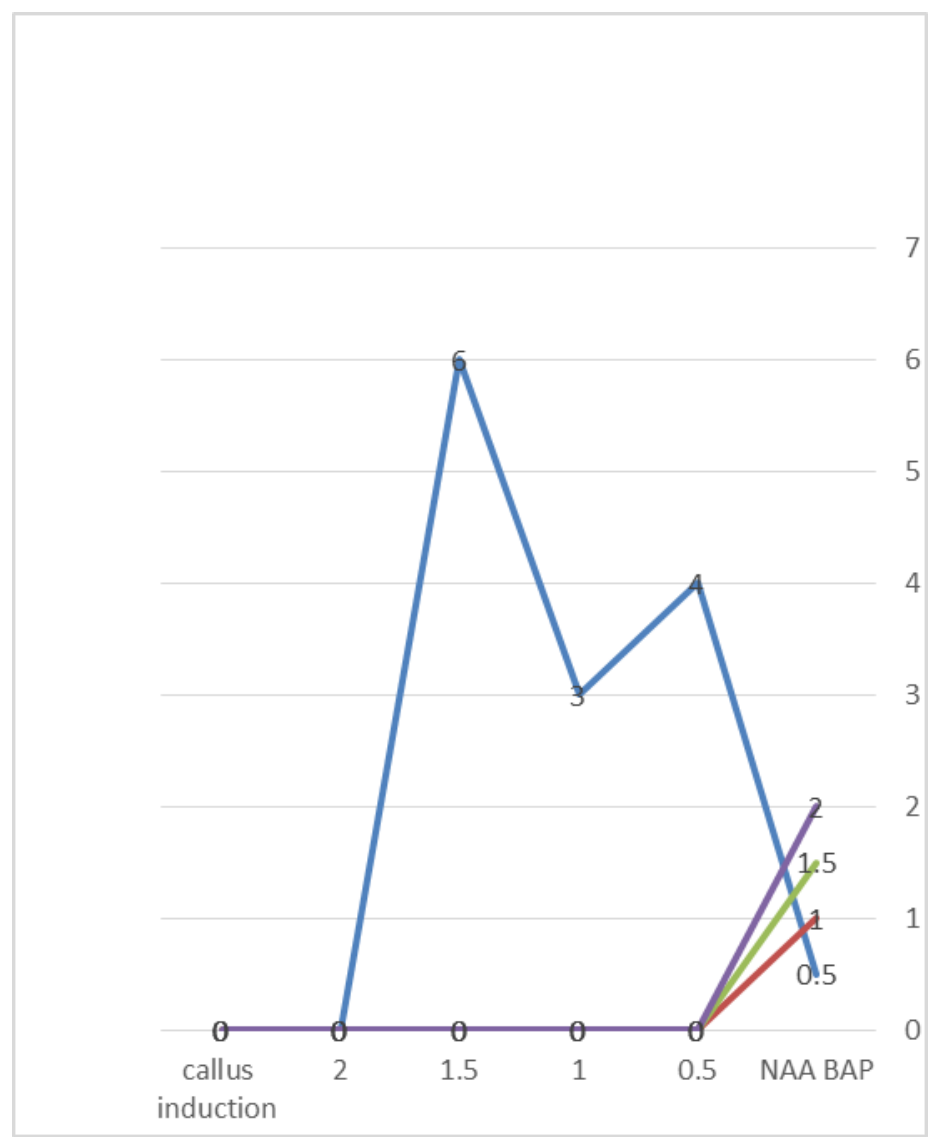

Figure 3. Callus induction with MS medium plus different concentrations of NAA, BAP 


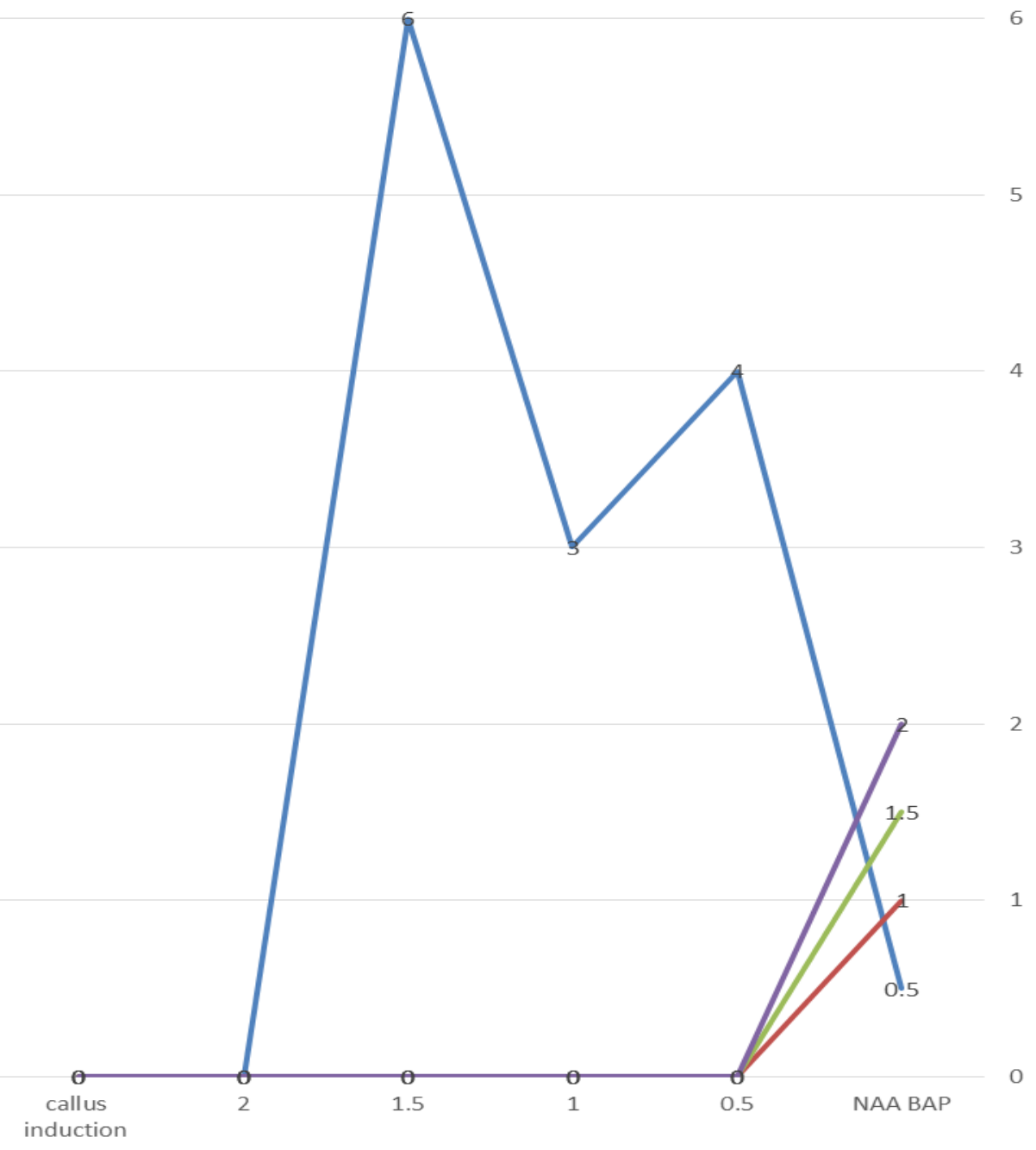

Figure 4. Callus induction with MS medium plus different concentrations of NAA, BAP

\section{References}

Aïdoud, A., Le Floc'h, É., \& Le Houérou, H. N. (2006). Les steppes arides du nord de l'Afrique. Science et changements planétaires/Sécheresse, 17(1), 19-30.

Amina, H., \& Mohamed, N. (2014). Prospects of increasing the presence of Helianthemum kahiricum Dell. pastoral North African plant by means of micropropagation. African Journal of Biotechnology, 13(7), 827-833. https://doi.org/10.5897/AJB2014.13611 
Belghith, A. (2003). Les indicateurs radiométriques pour 1 'étude de la dynamique des écosystèmes arides (région de Zougrata, Sud-Est tunisien). Science et changements planétaires/Sécheresse, 14(4), 267-274.

Díez, J., Manjón, J. L., \& Martin, F. (2002). Molecular phylogeny of the mycorrhizal desert truffles (Terfezia and Tirmania), host specificity and edaphic tolerance. Mycologia, 94(2), 247-259. https://doi.org/10.1080/15572536.2003.11833230

Escudero, A., Martínez, I., De la Cruz, A., Otálora, M., \& Maestre, F. (2007). Soil lichens have species-specific effects on the seedling emergence of three gypsophile plant species. Journal of Arid Environments, 70(1), 18-28. https://doi.org/10.1016/j.jaridenv.2006.12.019

Gonçalves, S., Fernandes, L., Pérez-García, F., González-Benito, M. E., \& Romano, A. (2009). Germination requirements and cryopreservation tolerance of seeds of the endangered species Tuberaria major. Seed Science and Technology, 37(2), 480-484. https://doi.org/10.15258/sst.2009.37.2.22

Mandeel, Q. A., \& Al-Laith, A. A. A. (2007). Ethnomycological aspects of the desert truffle among native Bahraini and non-Bahraini peoples of the Kingdom of Bahrain. Journal of ethnopharmacology, 110(1), 118-129. https://doi.org/10.1016/j.jep.2006.09.014

Murashige T, S. F. ((1962)). A revised medium for rapid growth and bioassays with tobacco tissue cultures. Physiol. Plant, 15, 473-497.

https://doi.org/10.1111/j.1399-3054.1962.tb08052.x

Plenchette, C., \& Duponnois, R. (2005). Growth response of the saltbush Atriplex nummularia L. to inoculation with the arbuscular mycorrhizal fungus Glomus intraradices. Journal of Arid Environments, 61(4), 535-540. https://doi.org/10.1016/j.jaridenv.2004.10.003

Raynaud, C. (1987). Atlanthemum Raynaud, un nouveau genre pour la famille des Cistaceae. Paper presented at the Anales Jard. Bot. Madrid.

Slama, A., Fortas, Z., Neffati, M., Khabar, L., \& Boudabous, A. (2006). Etude taxinomique de quelques Ascomycota hypogés (Terfeziaceae) de la Tunisie méridionale. Bulletin trimestriel de la Société mycologique de France, 122(2-3), 187-195.

Thorpe, T., Stasolla, C., Yeung, E., de Klerk, G., Roberts, A., \& George, E. (2008). Plant propagation by tissue culture. Volume 1. The background. The components of plant tissue culture media II: organic additions, osmotic and pH effects, and support systems. Springer, Dordrecht, 115-173.

\section{Copyright Disclaimer}

Copyright for this article is retained by the author(s), with first publication rights granted to the journal.

This is an open-access article distributed under the terms and conditions of the Creative Commons Attribution license (http://creativecommons.org/licenses/by/3.0/). 